\title{
Microalgae Microbial Fuel Cell (MMFC) using Chlorella vulgaris and "Batik" Wastewater as Bioelectricity
}

\author{
Nadiyah Faizi Polontalo ${ }^{1}$, Falvocha Alifsmara Joelyna ${ }^{1}$, Abdullah Malik Islam Filardli ${ }^{1}$, \\ Hadiyanto Hadiyanto ${ }^{1,2^{*}}$ and Zainul Akmar Zakaria ${ }^{1,3}$ \\ ${ }^{1}$ Chemical Engineering Department, Engineering Faculty, Diponegoro University, Indonesia \\ J1. Prof. Soedarto No. 13, Tembalang, Semarang 50275, Indonesia \\ ${ }^{2}$ Centre of Biomass and Renewable Energy (C-Biore), Diponegoro University, Indonesia \\ Jl. Prof. Soedarto No. 13, Tembalang, Semarang 50275, Indonesia \\ ${ }^{3}$ Bioprocess and Polymer Engineering Department, Faculty of Chemical and Energy Engineering, \\ University Teknologi Malaysia Jl. Iman, 81310 Skudai, Johor, Malaysia
}

\begin{abstract}
Nowadays, Indonesia is faced with an increase in human growth, and followed by increasing electricity demand. One of the environmental friendly alternative energy that can solve this problem is microbial fuel cell, which utilizes organic matter as a substrate of bacteria in carrying out its metabolic activities to produce electricity. In this study, investigated the electrical energy produced by Microalgae Microbial Fuel Cell (MMFC) using Chlorella vulgaris and "Batik" wastewater. This study aims to assess the performance of the MMFC system based on the influence of yeast ( $8 \mathrm{~g} \mathrm{~L}^{-1}$ and $\left.4 \mathrm{~g} \mathrm{~L}^{-1}\right)$, "Batik wastewater" concentration (50\% and $100 \%$ ), and graphite electrodes (1:1 and 2:2). The MMFC system was carried out by filling anode chamber with "Batik" wastewater and the cathode with $C$. vulgaris. MMFC simulation was operated for $7 \mathrm{~d}$. Concentration of $100 \%$ "Batik" wastewater and 2:2 number of electrodes gave the best result in MMFC with voltage 0.115 Volt, algae absorbance 0.666 . The COD decreased from $824 \mathrm{mg} \mathrm{L}^{-1}$ to $752 \mathrm{mg} \mathrm{L}^{-1}$ after the MMFC. The addition of $8 \mathrm{~g} \mathrm{~L}^{-1}$ yeast gave the optimum of bioelectricity production reached 0.322 Volt and the microalgae grew until the absorbance reached 1.031 .
\end{abstract}

Keywords: Wastewater, bioelectricity, Chlorella vulgaris, microbial fuel cell, waste to energy

\section{Introduction}

Nowadays, a crucial problem with the increase of human growth in Indonesia is the increasing electricity demand [1]. It is estimated to continue growing by $4.6 \% \mathrm{yr}^{-1}$ and less effort to increase electricity production, this condition will triple by 2030 . This condition made the availability of fossil energy, especially crude oil, increasingly scarce lead to Indonesia become a net importer of crude oil and its derivative products [2]. Amount one environmentally friendly alternative energy is a microbial fuel cell (MFC) by utilizing organic material (substrate) as an energy source of bacteria that its metabolic activities produce electricity. The system utilized wastewater as a substrate, could be used as an ideal tool for processing [3]. By utilizing Chlorella vulgaris [Beijerinck, 1890] and "batik" waste

\footnotetext{
${ }^{1}$ Corresponding author: hady.hadiyanto@gmail.com
} 
that convert biochemical compounds directly into electrical energy, yeast is used as a biocatalyst in improving the performance of MFC in the MMFC process [4].

C. vulgaris is a photosynthetic organism that has great $\mathrm{CO}_{2}$ fixation ability. This ability indirectly has a positive impact on reducing the effects of global warming [5]. C. vulgaris is also able to be used as a substrate in the system of microbial fuel cells which is an alternative source of electricity through hydrolysis and fermentation in a unit process [6].

Microbial fuel cell is a technology that utilizes microbes to produce energy in the form of electricity. Microbes convert various kinds of organic compounds into $\mathrm{CO}_{2}$, water, and energy [10]. Recently, one of MFC technologies developed is MMFC (Microalgae Microbial Fuel Cell) technology. MMFC is an alternative that be used as a source of electricity generator through hydrolysis and fermentation of microalgae in one process unit. MMFC consists of an anode and cathode that connected through a load (usually a resistor). Anode chamber is containing microorganism cultures that catalyses the composition of organic materials into electrons and protons. Power will be produced by the reduction of oxygen or other compounds at the cathode chamber [6]. On the operation of MFC, electrogene which will produce $\mathrm{CO}_{2}$. Microalgae in the cathode chamber use $\mathrm{CO}_{2}$ as a carbon source for growth [7].

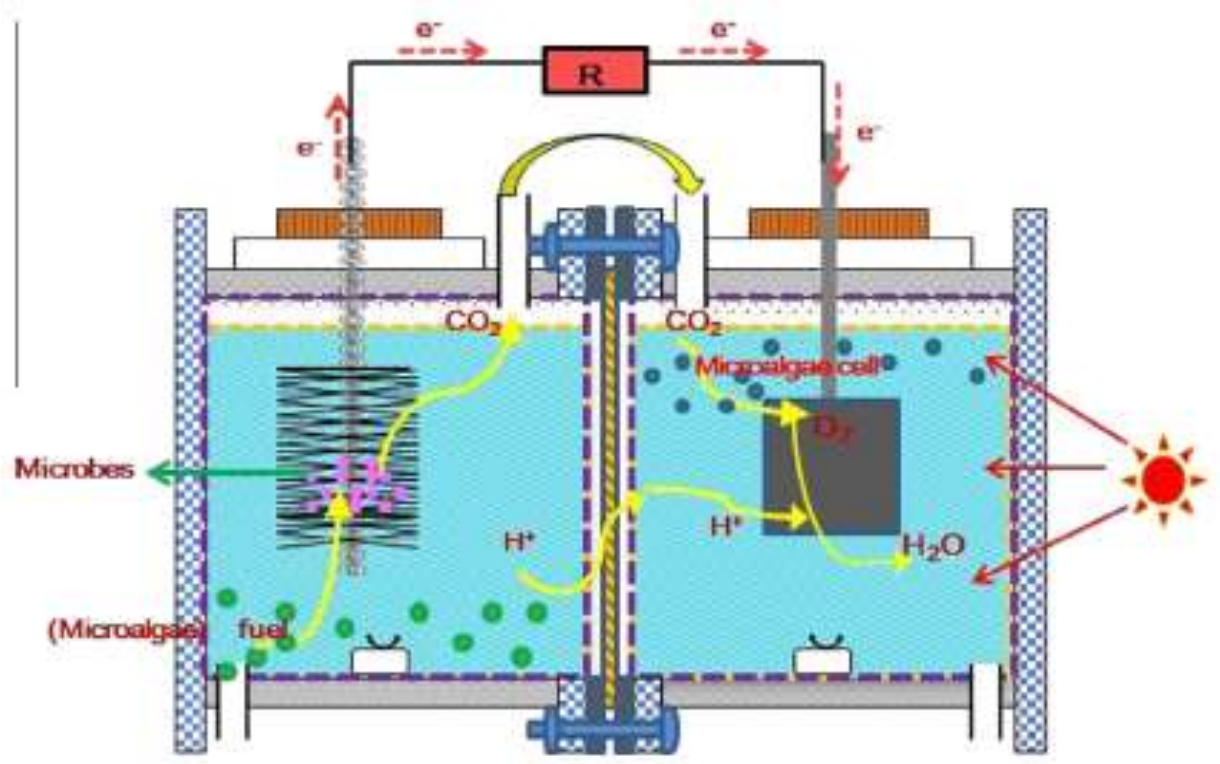

Fig. 1. MMFC operating system [7].

The application of Chlorella sp. in liquid waste, reduce levels of pollutants such as BOD, COD with a range $89 \%$ to $96 \%$ in the logarithmic phase and $80 \%$ to $95 \%$ in the stationary phase [8]. In this study, research was conducted on the electrical energy produced by MMFC using C. vulgaris and "batik" waste (from Figa Batik Collection) in Semarang, Indonesia. The results of this study are also expected to be one step forward to obtain renewable energy sources so that the use of MFC systems with wastewater substrates can reduce fossil energy consumption [9]. 


\section{Materials and methods}

\subsection{Materials}

The materials used in this study are $C$. vulgaris as catholyte which obtained from the Centre of Biomass and Renewable Energy (C-Biore) Integrated Laboratory Diponegoro University, "batik" liquid waste as anolyte with $100 \%$ and $50 \%$ concentration which obtained from Griya Batik Semarang (Figa Batik Collection Rejomulyo Semarang). Graphite electrode with a length of $10 \mathrm{~cm}$ and a diameter of $10 \mathrm{~mm}$ with a ratio 1:1 and 2:2 electrode obtained from an online store in Jakarta, yeast with mass of $4 \mathrm{~g} \mathrm{~L}^{-1}$ and $8 \mathrm{~g} \mathrm{~L}^{-1}$, $\mathrm{NaHCO}_{3} 0.32 \mathrm{~g} \mathrm{~L}^{-1}$, Urea $0.05 \mathrm{~g} \mathrm{~L}^{-1}$, and TSP $0.05 \mathrm{~g} \mathrm{~L}^{-1}$. Besides, the utilization used in this study were glass box, digital multimeter, connecting wire, $\mathrm{CO}_{2}$ wire, aeration wire, aerator, graphite electrode, lamp, ballast, and lux meter.

\subsection{Methods}

\subsubsection{Cultivation of chlorella vulgaris}

Amounted $1 \mathrm{~L}$ of $C$. vulgaris was diluted to $2 \mathrm{~L}$, then add the nutrients of $0.64 \mathrm{~g} \mathrm{NaHCO}_{3}$, $0.1 \mathrm{~g}$ urea, and $0.1 \mathrm{~g}$ TSP, then stirred. During cultivation, lighting and oxygen were given through the aerator, then cover them with clear plastic. The absorbance or Optical Density (OD) check daily. If the absorbance approaches 0.6 , then $C$. vulgaris was ready to use.

\subsubsection{MMFC making process}

"Batik" wastewater was diluted to concentration according to treatments $100 \%$ and $50 \%$, then check the OD absorbance using a spectrophotometer. The anode chamber (anolyte) is filled with $1 \mathrm{~L}$ of waste. Meanwhile, at the cathode chamber (catholyte) is filled with $1 \mathrm{~L}$ of C. vulgaris. Followed, putting in the graphite electrodes with a number of 1:1 and 2:2 bar, and $4 \mathrm{~g}$ and $8 \mathrm{~g}$ of yeast added. Then, turn on the lamp, $20 \mathrm{~cm}$ far from the reactor.

\subsubsection{Simulation of MMFC}

The MMFC system was operated for $7 \mathrm{~d}$, then every $24 \mathrm{~h}$, the voltage and current are measured as well as the COD levels in the reactor. Data in the form of current strength (I) and voltage $(\mathrm{V})$ would be calculated into power density, which was the power per unit area of the electrode (A), by using the Equation (1):

$$
P=\frac{\mathrm{V} \times \mathrm{I}}{\mathrm{A}}
$$

Note:

$\mathrm{P} \quad=$ Power density (Watt)

$\mathrm{V}=$ Voltage $(\mathrm{mV})$

I $=$ Current $(\mathrm{mA})$

A $=$ Area of electrode $\left(\mathrm{mm}^{2}\right)$ 


\subsubsection{Measurement of chemical oxygen demand level}

Chemical oxygen demand (COD) was defined as the amount of oxygen equivalents consumed in the organic compounds of samples by oxidizing agents. The higher COD, the higher the amount of pollutant in the water sample. "Batik" wastewater measured its COD level before and after the MMFC process with a COD photometer with an operating condition by $150^{\circ} \mathrm{C}$ for $2 \mathrm{~h}$ in the COD reactor.

\section{Results and discussions}

\subsection{The effect of the concentration of "batik" wastewater on MMFC performance}

\subsubsection{Bioelectricity production}

Bioelectricity refers to electrical potentials and currents occurring within or produced by living organisms. It results from the conversion of chemical energy into electrical energy. The influence of wastewater concentration on $C$. vulgaris growth and bioelectricity production presented in Figure 2 and Figure 3.

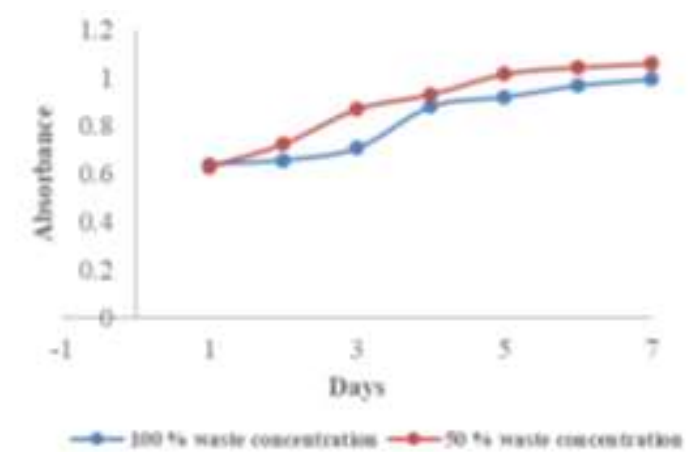

Fig. 2. Effect of wastewater concentration on $C$. vulgaris growth

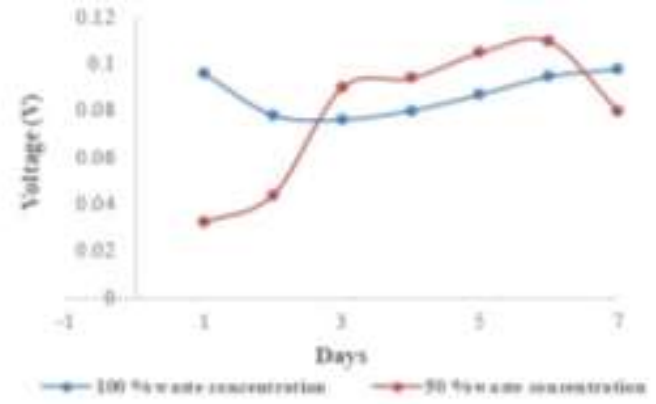

Fig. 3. Bioelectricity production every day on the influence of wastewater concentration

Figure 2 defined the absorbance obtained on the $6^{\text {th }} \mathrm{d}$ on $100 \%$ waste concentration was 1.045 . While, Figure 3 showed the highest voltage was obtained on the $6^{\text {th }} \mathrm{d} .100 \%$ waste concentration, and 1:1 electrode number which is 0.11 Volt, while on $50 \%$ waste concentration and 1:1 electrode obtained 0.095 Volt. Electricity production has been 
decreased on the last day of the MMFC process, because microalgae could produce biofilms which is have the effect of increasing the resistance in the anode and caused a decrease in the electric voltage and current generated.

\subsubsection{Chemical oxygen demand analyzation}

The highest COD was obtained in $100 \%$ waste concentration. The value before the MMFC implementation process was $460 \mathrm{mg} \mathrm{L}^{-1}$ and after the process, the COD was decreased by $266 \mathrm{mg} \mathrm{L}^{-1}$. The reactor generated power density amounted to $27.07 \mathrm{~mW} \mathrm{~m}^{-2}$. The result found that the MMFC process has made the value of the COD was decreased, and the wastewater would be safe to the environment.

\subsection{The effect of the number of electrode on MMFC performance}

\subsubsection{Bioelectricity production}

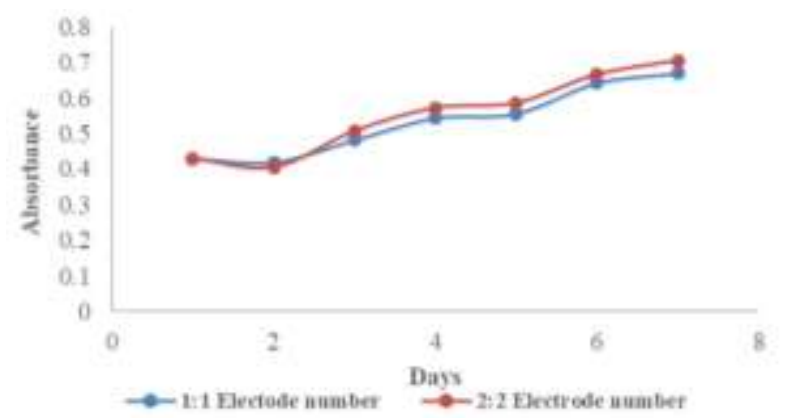

Fig. 4. Effect of number of electrodes on C. vulgaris growth

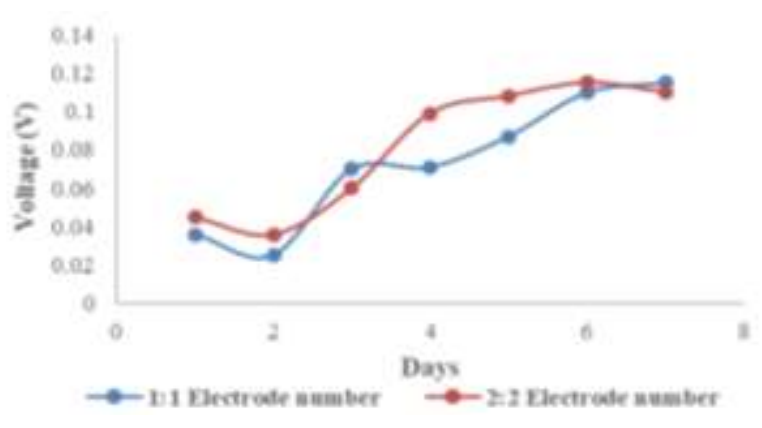

Fig. 5. Bioelectricity production every day on the influence of the number of electrodes

Growth of C. vulgaris showed same patterns with the electrodes number (Fig. 4). From $1 \mathrm{~d}$ to $5 \mathrm{~d}$, the voltage tends to increase daily, but there is decreasing on the $1 \mathrm{~d}$ and $2 \mathrm{~d}$ for both variables with 1:1 and 2:2 number of electrodes, became 0.025 Volt and 0.036 Volt. In line with algae growth that still in stage of adaptation to the environment on the first $2 \mathrm{~d}$. The optimum result was obtained on variable $2: 2$ electrodes on the $6^{\text {th }} \mathrm{d}$, a voltage of 0.115 Volt and algae absorbance of 0.666 . 


\subsubsection{Chemical oxygen demand analyzation}

The results of the COD analysis on the wastewater showed that the COD value decreased from $824 \mathrm{mg} \mathrm{L}^{-1}$ to $752 \mathrm{mg} \mathrm{L}^{-1}$ after the MMFC process was carried out. This indicated that the dissolved oxygen amount in the wastewater decreased approach the maximum threshold, which is $150 \mathrm{mg} \mathrm{L}^{-1}$ [11]. Based on the research, it has been proven in the MMFC process, and there was a synergetic relationship between the degradation of components in wastewater with the cultivation of microalgae used to produce environmental friendly bioelectricity [7].

\subsection{The effect of the addition of yeast on MMFC performance}

\subsubsection{Bioelectricity production}

Effect of yeast addition on C. vulgaris growth and bioelectricity production presented on Figure 5 and Figure 6.

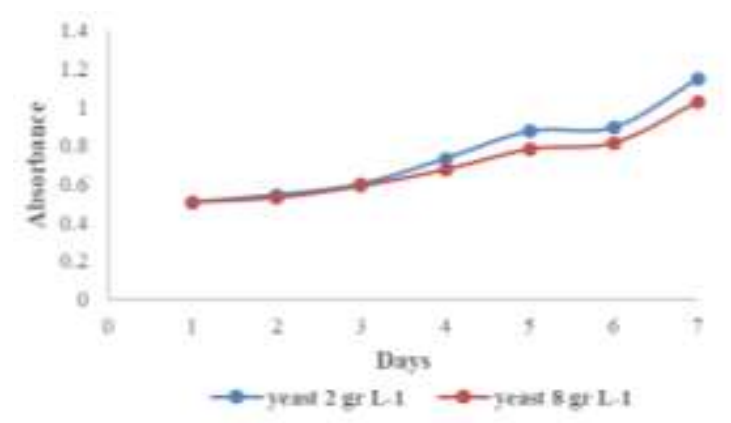

Fig. 5. Effect of yeast addition on C. vulgaris growth

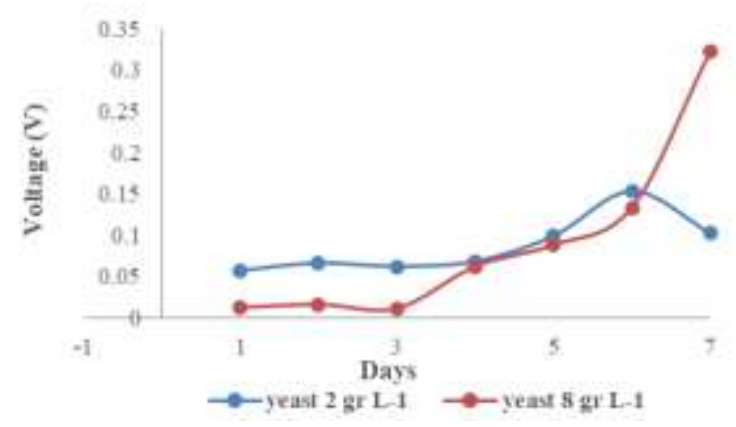

Fig. 6. Bioelectricity production every day on the influence of the addition of the yeast

The growth of $C$. vulgaris slightly higher on yeast addition of $2 \mathrm{~g} \mathrm{~L}^{-1}$ (Figure 5). The voltage increased daily, except for the addition of yeast variable $2 \mathrm{~g} \mathrm{~L}^{-1}$, the voltage decreases on $7 \mathrm{~d}$. The optimum value from the addition of $2 \mathrm{~g} \mathrm{~L}^{-1}$ yeast is 0.103 Volt, while the addition of $8 \mathrm{~g} \mathrm{~L}^{-1}$ yeast is 0.322 Volt. The decreasing voltage is caused by the metabolism of bacteria producing hydrogen, that accumulated over time and cover the electrodes, thus reducing electron transfer and decreased electricity production [4]. Meanwhile, the optimum bioelectricity is obtained by adding yeast $8 \mathrm{~g} \mathrm{~L}^{-1}$, the voltage 
increased daily and the highest value reaches 0.322 Volt. Increasing number of yeasts, improve the chance of oxidizing waste and electron exchange.

\subsubsection{Chemical oxygen demand analyzation}

The results of COD measurements carried out on "Batik" wastewater with the addition of $2 \mathrm{~g} \mathrm{~L}^{-1}$ yeast showed that the COD value decreased from $957 \mathrm{mg} \mathrm{L}^{-1}$ to $568 \mathrm{mg} \mathrm{L}^{-1}$ after the MMFC process, and become $493 \mathrm{mg} \mathrm{L}^{-1}$ in $8 \mathrm{~g} \mathrm{~L}^{-1}$ yeast. The addition of yeast to the waste increased MMFC's ability to degrade components of the waste. Yeast as a catalyst in oxidizing waste made better electron transfer.

\section{Conclusion}

Concentration of $100 \%$ "Batik" wastewater and 2:2 number of electrodes gave the best result in MMFC process with the highest voltage found to be 0.115 Volt with the algae absorbance of 0.666 . The COD value also decreased from $824 \mathrm{mg} \mathrm{L}^{-1}$ to $752 \mathrm{mg} \mathrm{L}^{-1}$ after the MMFC process. Yeast addition to "Batik" wastewater has a significant effect on the results of the MMFC process. The addition of $8 \mathrm{~g} \mathrm{~L}^{-1}$ yeast gave the optimum of bioelectricity production, which is reached 0.322 Volt and the microalgae also grew until the absorbance reached 1.031 .

\section{References}

1. I. Kholiq. J. IPTEK. 19,2:75-91(2015). [in Bahasa Indonesia] https://doi.org/10.31284/j.iptek.2015.v19i2.12

2. P. Y. So. J. Grad. Unpar. 1,1:1-13(2014). [in Bahasa Indonesia]. http://journal.unpar.ac.id/index.php/unpargraduate/article/view/837

3. B. Ibrahim, P. Supitjah, Z. N. Adjani. JPHPI. 20,2:296-304(2017). [in Bahasa Indonesia].

http://jurnal.ipb.ac.id/index.php/jphpi/article/view/19813/13679

4. L. Iradati, G. Samudro, S. Sumiyati. Jurnal Teknik Lingkungan. 4,2:200-206(2015). [in Bahasa Indonesia]. https://www.neliti.com/publications/192345/pengaruh-konsentrasi-chemicalbiological-demand-cod-dan-ragi-terhadap-kinerja-du

5. Dianursanti, R. Nuzulliany, A. Wijanarko, M. Nasikin. Jurnal Teknik Kimia Indonesia. 8,3:87-93(2009). [in Bahasa Indonesia]. https://doi.org/10.5614/jtki.2009.8.3.3

6. S. B. Velasquez-Orta, T. P. Curtis, B. E. Logan. Biotech and Bioeng. 103,6:10681076(2009). https://doi.org/10.1002/bit.22346

7. Y. Cui, N. Rashid, N. Hu, M. S. U. Rehman, J. Han. Erg. Conv. and Mgt. 79:674680(2014). https://doi.org/10.1016/j.enconman.2013.12.032

8. F. Hartini, F. Restuhadi, T. Dahril. JOM FAPERTA. 4,1:1-13(2017). https:/www.neliti.com/publications/202320/pemanfaatan-mikroalga-chlorella-spdalam-menurunkan-baku-mutu-polutan-limbah-cai

9. L. He, P. Du, Y. Chen, H. Lu, X. Cheng, B. Chang, Z. Wang. Ren. and Sustain. Erg. Rev. 71:388-403(2017). https://doi.org/10.1016/j.rser.2016.12.069 
10. E. Kristin. Produksi energi listrik melalui microbial fuel cell menggunakan limbah industri tempe. [Electricity production through microbial fuel cell using wastewater from tempeh industry] [Thesis] Teknologi Bioproses, Universitas Indonesia (2012). p.5. [in Bahasa Indonesia]. http://lib.ui.ac.id/file?file=digital/20311042-S43242Produksi\%20energi.pdf

11. R. H. Olivera, A. D. Gonza, U. Y. Pari, P. Vega, M. R. Urgarte, J. Tapia, L. Molina, A. L. Rivera, D. G. P. Salazar, M. Esparza. Elc. J. of Biotech. 31:34-43(2018). https://doi.org/10.1016/j.ejbt.2017.10.013

12. L. E. Wall, Sharon B, Velasquez-Orta, E. R. Frasca, P. Leary, I. Yanez, Noguez, M. T. O. Ledesma. Biochem. Eng. J. 151:107319(2019). https://doi.org/10.1016/j.bej.2019.107319

13. C. Safi, B. Zebib, O. Merah, P. Y. Pontailer, C. V. Garcia. Renew. Sust. Energ. Rev. 35: 265-278(2014). https://doi.org/10.1016/j.rser.2014.04.007

14. D. P. Aghni. Pengolahan Air Limbah Batik dengan Reaktor yang Berisi Tanaman Eceng Gondok [Batik Wastewater Treatment with Reactors Containing Water Hyacinth Plants] [Thesis] Teknik Sipil, Universitas Sebelas Maret (2017). [in Bahasa Indonesia].p.13. https://eprints.uns.ac.id/36460/ 